\title{
Efficacy of partial purified bacteriocin of Pseudomonas aeruginosa on Methicillin-resistant Staphylococcus aureus biofilm
}

\author{
Arumugam Thangarasu, Dhanam Selvam, Sampath Gattu, Kayalvizhi Nagarajan* \\ Department of Zoology, School of Life Sciences, Periyar University, Salem-636011, Tamil Nadu, India
}

\begin{abstract}
Biofilms are microbial communities that cause serious chronic infections in the environment by enhancing antimicrobial resist ance. Bacteria in the biofilm can be up to a thousand times more resistant to antibiotics than the same bacteria circulating in a planktonic state. The emergence of antibiotic-resistant microorganism has led to the exploration of different therapeutic agents like ribosomally synthesized microorganism peptides referred to as bacteriocins. In this study, bacteriocin producing bacteria Pseudomonas aeruginosa isolated from a soil sample. It was found to be effective against Methicillin-resistant Staphylococcus aureus (MRSA). Furthermore the bacteriocin was partial purified by ammonium sulfate, the precipitate has highly effective against MRSA (400AU/mL). MRSA cells were treated with precipitated culture supernatant of $P$. aeruginosa TA6 was analyzed by FT-IR. The treated and untreated MRSA showed band variations at 682.59 and $3442.15 \mathrm{~cm}^{-1}$ corresponding to the alkyl and amide group respectively. Bacteriocin showed marked inhibition activity against the biofilm of MRSA. About $0.05 \%$ and $0.02 \%$ attachment of biofilm was observed in the presence of $1 \mathrm{X}$ MIC (10 $\mu$ g/mL) and $2 \mathrm{X}$ MIC $(20 \mathrm{~g} / \mathrm{mL})$ respectively. Our results recommend that bacteriocins that make stable pores on biofilm cells are extremely potent for the treatment of MRSA biofilm infections.
\end{abstract}

Keyword: P. aeruginosa TA6; Bacteriocin; MRSA; Biofilm; FT-IR

Article Info: Received 06 July 2019; $\quad$ Review Completed 17 Aug 2019; $\quad$ Accepted 22 Aug 2019; Available online 30 Aug 2019

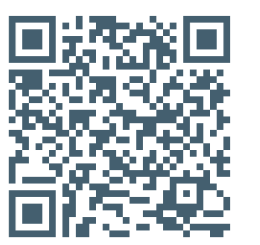

\section{Cite this article as:}

Thangarasu A, Selvam D, Gattu S, Nagarajan K, Efficacy of partial purified bacteriocin of Pseudomonas aeruginosa on Methicillin-resistant Staphylococcus aureus biofilm,, Journal of Drug Delivery and Therapeutics. 2019; 9(4-A):438-441 http://dx.doi.org/10.22270/jddt.v9i4-A.3464

Dr. Nagarajan Kayalvizhi, Assistant Professor, Department of Zoology, Periyar University, Salem - 636011 Tamil Nadu, India.

\section{INTRODUCTION}

Biofilms are often associated with chronic disease states that create long-term problems for environment. Biofilms have been known to throw into physical and chemical protection as well as defense from antimicrobials ${ }^{1}$. In clinical settings, the continued existence of biofilms on medical devices and hospital equipment permits certain pathogens to easily transmit a disease to patients. Once infected, pathogenassociated biofilms can avoid human host immune defenses and are frequently associated with persistent infections, often resistant to antibiotic therapy ${ }^{2}$. Away from antimicrobial resistance, bacteria present in a biofilm are also defiant to various physicochemical stresses, enabling biofilms to persist in even the harshest of conditions. In the food industry, biofilms can cause food-borne disease outbreaks. Furthermore, inefficient cleaning commands may be a causative factor in the spread of resistance in hospital environments ${ }^{3}$.

A recent comprehensive review described the efficacy of antibiotics in combination with other antimicrobial peptides and essential oils, as well as the effectiveness of biofilmdegrading enzymes, quorum sensing inhibitors and nanoparticles as potential antibiofilm agents 4 . Due to the extensive resistance of biofilms to conventional antibiotics, one alternative avenue to embark upon this problem is to harness bacteriocins as antimicrobials either independently or in combination with existing proven antimicrobials, to target biofilms. The major differentiation between bacteriocins and antibiotics is that bacteriocins restrict their activity to strains of species associated with the producing species and particularly to strains of the same species. Besides, bacteriocins are ribosomally synthesized and produced throughout the primary phase of growth, though antibiotics are usually secondary metabolites ${ }^{5}$. Bacteriocins usually have a low molecular weight (rarely over $10 \mathrm{kDa}$ ) they undergo posttranslational modification and can be easily degraded by proteolytic enzymes especially by the proteases of the mammalian gastrointestinal tract, which makes them secure for human consumption. 
Bacteriocins are in general cationic, amphipathic molecules as they contain an excess of lysyl and arginyl residues, 6 . There are some reports available on bacteriocin-producing Pseudomonas aeruginosa isolated from soil samples but limited studies describe soil isolates ${ }^{8}, 9$. P. aeruginosa can compete, is by producing chromosomally encoded bacteriocins, called pyocins. Pyocins are ribosomally synthesized bacteriocins which are produced to kill competitors of the same species ${ }^{10}$. The pyocins produced by $P$. aeruginosa are classified into three major types: S, R- and F-pyocins ${ }^{11}$. R- and F-type pyocins are produced by more than $90 \%$ of $P$. aeruginosa strains, while $70 \%$ of $P$. aeruginosa strains can produce at least one S-type pyocin. The present study was partially purified bacteriocin extracted from $P$. aeruginosa TA6 culture showed biofilm activity against Methicillin-resistant Staphylococcus aureus (MRSA).

\section{MATERIALS AND METHODS}

\section{Preparation and partial purification of Bacteriocin}

The bacteriocin producing bacteria $P$. aeruginosa TA6 was grown in Luria broth and it was incubated at $37{ }^{\circ} \mathrm{C}$ for 18 hours. The following time, the culture broth was subjected to centrifugation at $10,000 \mathrm{rpm}$ for $15 \mathrm{~min}$ at $4{ }^{\circ} \mathrm{C}$ for separation of bacterial cells. The supernatant was filtersterilized by passing through a $0.45 \mu \mathrm{m}$ pore sized filter membrane (Millipore, MA, USA). This CFS was further partially purified by ammonium sulfate precipitation ${ }^{12}$. To achieve the maximum saturation of bacteriocin, $70 \%$ of ammonium sulfate was added by constant agitation at $4{ }^{\circ} \mathrm{C}$ at overnight. Then precipitates were recovered by centrifugation at $10,000 \mathrm{rpm}$ for $30 \mathrm{~min}$ at $4{ }^{\circ} \mathrm{C}$. The resulting pellets were re-suspended in $20 \mathrm{mM}$ sodium phosphate buffer ( $\mathrm{pH}$ 7.2) and were designated as 'partially purified bacteriocin'13. For removal of the salt from the partially purified bacteriocin, ultra-filtration was done through a pre-treated dialysis tubing of 6-8 kDa cutoff size ${ }^{12}$ The active fractions, thus obtained, were collected and pooled for assessment of inhibitory activity 14 . The bioactivity of bacteriocin was analyzed at each point of purification by agar well diffusion assay (AWDA), in terms of $\mathrm{AU} / \mathrm{mL}$. After partial purification, protein concentration was measured ${ }^{15}$.

\section{FT-IR Analysis}

Determining the possible functional groups by FT-IR analysis was performed using Perkin Elmer to detect the characteristic peaks and their functional groups. The vibration pattern that appears in the infrared spectra provides information about the chemical functional group of the sample. $100 \mathrm{AU} / \mathrm{mL}^{-1}$ bacteriocin prepared and $10 \times 0.6$ OD indicator strain were mixed and incubated at $37{ }^{\circ} \mathrm{C}$ for $1 \mathrm{~h}, 2 \mathrm{~h}$, and $3 \mathrm{~h}$. The control was used as without bacteriocin culture. A fraction of the sample was encased directly in the sample holder and spectra were scanned from 3442 to 682 $\mathrm{cm}^{-1}$.

\section{Biofilm Formation Assay}

Methicillin-resistant Staphylococcus aureus was grown on Luria broth (LB; Himedia) at $37{ }^{\circ} \mathrm{C}$ for 18 h. $200 \mu \mathrm{L}$ of bacterial cell suspension (about $10^{6} \mathrm{CFU} / \mathrm{mL}$ ) in Luria broth (LB) were inoculated in triplicates to wells of a tissue culture polystyrene 96-well plate. Biofilms were developed for $48 \mathrm{~h}$ at $37{ }^{\circ} \mathrm{C}$. Subsequently, the medium was removed and the biofilms were washed twice with $250 \mu \mathrm{L}$ of sterile phosphate-buffered saline (PBS, pH 7.2). Biofilms were fixed with $200 \mu \mathrm{L}$ of methanol per well for $15 \mathrm{~min}$ and stained with $200 \mu \mathrm{L}$ of $1 \%$ crystal violet per well (Sigma-Aldrich, Steinheim, Germany). After that, the plates were rinsed with distilled water and air-dried. Crystal violet was solved in $96 \%$ ethanol to measure absorbance at $492 \mathrm{~nm}$ in a microplate reader (Bio-Rad, USA). Each assay was performed three times and the results were averaged. Values of absorbance $<0.2$ were considered to be weak producers, $0.2-0.4$ were medium producers, and values $>0.4$ were considered strong producers 16 .

\section{RESULTS}

Partial purification of bacteriocin from a soil isolate Pseudomonas aeruginosa TA6

The crude bacteriocin preparation obtained from the cellfree supernatant of $P$. aeruginosa TA6 after ammonium sulfate saturated precipitation $(70 \%)$ was subjected to purification. The ultrafiltration of the crude bacteriocin was achieved by using dialysis tubing of cut off size 6-8 $\mathrm{kDa}$. The bacteriocin activity was carried against Methicillin-resistant Staphylococcus aureus (MRSA) by agar well diffusion assay. The maximum antagonistic activity was observed to be 400 $\mathrm{AU} / \mathrm{mL}$ in the resolved partial purified bacteriocin. (Fig 1)

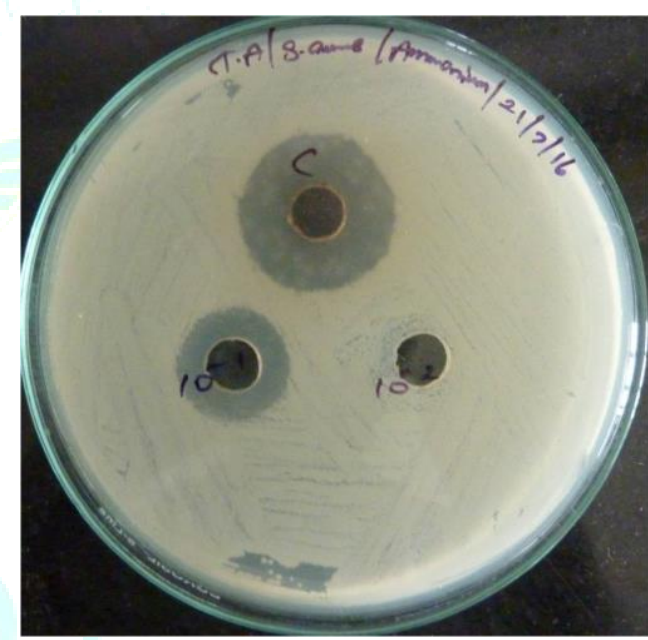

Fig 1. Partially purified bacteriocin against MRSA

\section{Fourier Transmission-Infra Red Analysis (FT-IR)}

The FT-IR spectral analysis of the extracellular extract of $P$. aeruginosa TA6 strain revealed that the spectral range of obtained functional group ranged was between 400 and $4000 \mathrm{~cm}^{-1}$ from the results, it was observed that the peak signal recorded for $682.59,1046.13,1103.95,1165.28$, $1638.22,2078.63,2931.77$ and 3442.15 . The peak observed at 682.59 , was due to the alkyl group $(\mathrm{C}-\mathrm{Cl})$. The vibration stretch recorded at 1046.13 aromatic groups (C-Br), 1103.95 aromatic group (C-F), 1165.28 aromatic group (C-F). The sharp peak at $1638.22 \mathrm{~cm}^{-1}$ was due to the presence of $\mathrm{N}, \mathrm{N}$ disubstituted Amides. The small vibration stretch recorded at $2078.63 \mathrm{~cm}^{-1}$ represents the possible presence of thiocyanate $(-\mathrm{N}=\mathrm{C}=\mathrm{S})$. Finally broadband at $3442.15 \mathrm{~cm}^{-1}$ showed the presence of amide group (-CONH-) (Fig.2) 


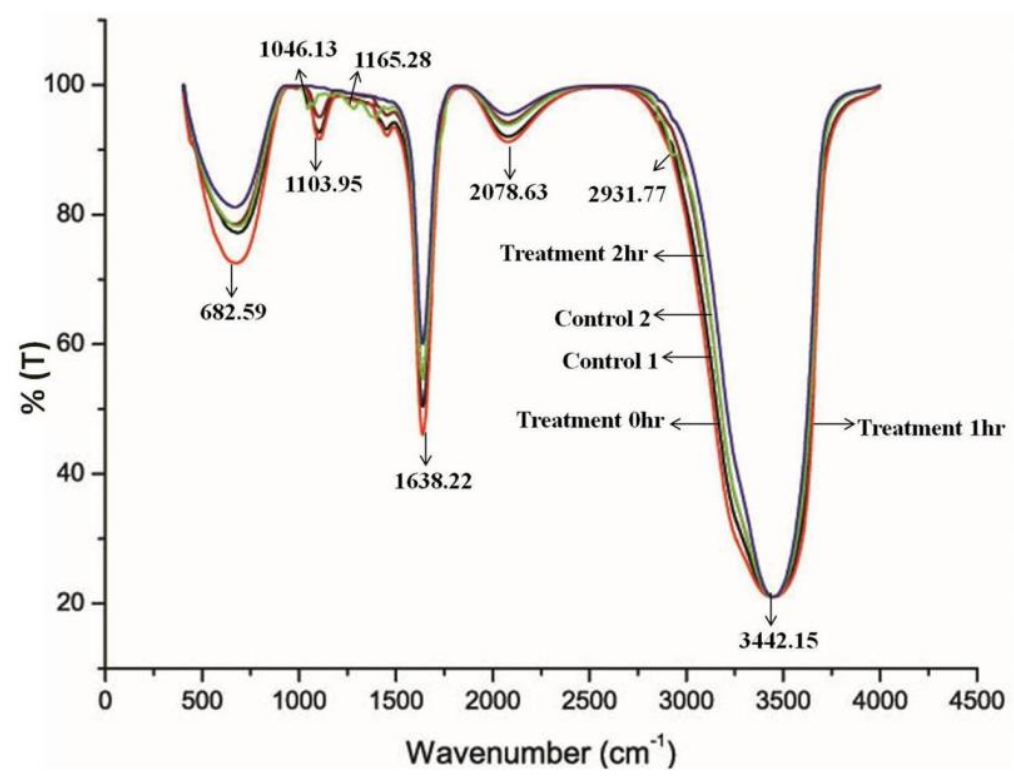

Fig 2. Bacteriocin functional group identified by FT-IR analysis.

\section{Biofilm inhibition by bacteriocin.}

When different concentrations of bacteriocin were incubated with Methicillin-resistant $S$. aureus for $4 \mathrm{~h}$ at $37^{\circ} \mathrm{C}$ for adherence to the wells of microtiter plates, it inhibited biofilm attachment in a concentration-dependent manner. About $0.05 \%$ and $0.02 \%$ attachment of biofilm was observed in the presence of $1 \mathrm{X}$ MIC $(10 \mu \mathrm{g} / \mathrm{mL})$ and $2 \mathrm{X}$ MIC $(20$ $\mu \mathrm{g} / \mathrm{mL}$ ) respectively. Bacteriocin showed significant inhibitory activity against Methicillin-resistant $S$. aureus biofilm formation at $48 \mathrm{~h}$, about its concentration. For the non-treated controls, a biofilm formed consisted of nearly uniform, a thick layer of cells. While the biofilm treated with bacteriocin $10 \mu \mathrm{g} / \mathrm{mL}$ and $20 \mu \mathrm{g} / \mathrm{mL}$ was much less dense, and individually formed colonies could be seen (Fig. 3).

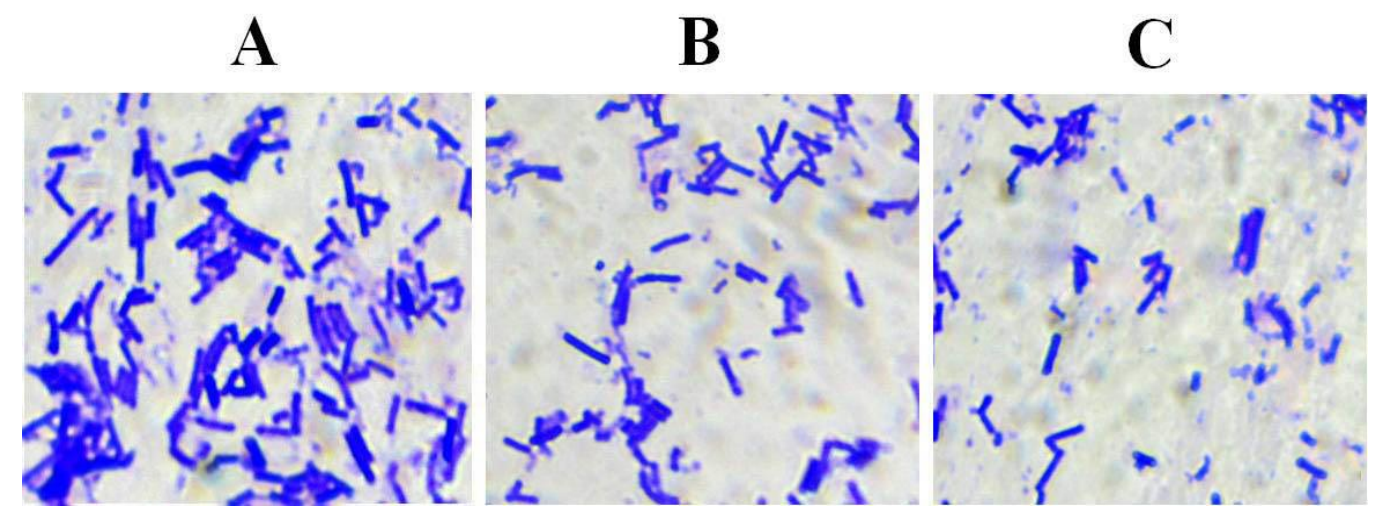

Fig 3. Biofilms treated with bacteriocin assessed by microscopy: A. non-treated control; $B$. Treated with bacteriocin $1 X$ MIC $(10 \mu \mathrm{g} / \mathrm{mL}) ;$ C. Treated with bacteriocin 2X MIC $(20 \mu \mathrm{g} / \mathrm{mL})$.

\section{DISCUSSION}

The growth of biofilms is a significant problem within the healthcare and food industries. Control of biofilms formed by microbial pathogens is an important subject for medical researchers since the development of biofilms on foreignbody surfaces often causes biofilm-associated infections in patients with indwelling medical devices. The characteristic resistance offered by biofilm-associated communities of microorganisms leading to their persistent survival is an important challenge to address. Though, many antibiotics are effective against biofilms ${ }^{17}$. Furthermore, while it is suggested that bacteriocins may inhibit the development of biofilms ${ }^{18}$, their effect upon microbial cells in a biofilm is not fully understood. Methicillin-resistant Staphylococcus aureus (MRSA) is an alarming threat of interest that is responsible for either community-acquired (CA-MRSA) or health-careacquired (HA-MRSA) infections. Staphylococcus aureus is an opportunistic pathogen causing a broad range of nosocomial and community-acquired infections. Diseases caused by this bacterium can range from skin infections to foodborne illnesses and severe infections such as endocarditis, osteomyelitis, and sepsis ${ }^{19}$. The continuous use of antibiotics has resulted in multiresistant bacterial strains all over the world 20 . Consequently, there is an urgent need to search for alternatives to synthetic antibiotics.

Bacteriocins are the peptides and protein antibiotics which are produced by several species and have antimicrobial properties usually against other closely related species 21. There are some reports available on bacteriocin-producing $P$. auroginosa isolated from soil samples but limited studies describe soil isolates ${ }^{8}, 9$. Bacteriocins of $P$. aeruginosa present an example of such excellence as $>90 \%$ of its strains produce bacteriocins called Pyocins 10, 22, 23. In this study, the effects of bacteriocin from $P$. aeruginosa TA6 against Methicillin-resistant staphylococcus aureus (MRSA). Among the bacteriocins, showed the highest bactericidal activities 
against biofilm cells. The partially purified bacteriocin has shown the highest activity (400AU/mL) against MRSA. The FT-IR spectrum of $P$. aeruginosa TA6 bacteriocin treated with MRSA. The strain was revealed that functional range at 300 and $4000 \mathrm{~cm}^{-1}$. In bacteriocin treated cells shift in absorbance in low frequency at $682.59,1046.13,1103.95$, 1165.28, 1638.22, 2078.63, 2931.77 and $3442.15 \mathrm{~cm}^{-1}$. FT-IR spectroscopy has been applied as a reliable method to study the putative mode of action of cell lytic bacteriocins from $P$. aeruginosa on $S$. aureus. However, our result was contradicted the earlier report 24 . The fall in the emergence of new antimicrobials in the market during the past two decades is worrying, particularly given the rise in bacterial resistance against many of the currently used antibiotics. In addition to antimicrobial activities, bacteriocins serve as an anti-resistance compound to classic antibiotics as they can interact with bacterial membranes, create ion-permeable channels leading to increased cytoplasmic membrane permeability and hence, bacterial cell death ${ }^{25}$. When applied to preformed MRSA biofilms, bacteriocin was able to significantly reduce biofilm cell viability even at lower concentrations at 24-h incubation. These results suggest that bacteriocin is controlling for the growth of MRSA biofilm. Our results suggest that bacteriocins that form stable pores on biofilm cells are highly potent for the treatment of MRSA biofilm infections.

\section{REFERENCES}

1. Donlan R. Biofilms: microbial life on surfaces. Emerg Infect Dis, 2002; 8: 881-890.

2. Kostakioti M, Hadjifrangiskou M, Hultgren SJ. Bacterial biofilms: development, dispersal, and therapeutic strategies in the dawn of the postantibiotic era. Cold Spring Harb Perspect Med, 2013; 3:a010306.

3. Simoes M, Simões LC, Vieira MJ. A review of current and emergent biofilm control strategies. LWT Food Sci Technol, 2010; 43: 573-583.

4. Algburi A, Comito N, Kashtanov D, Dicks LM, Chikindas ML. Control of biofilm formation: antibiotics and beyond. Appl Environ Microbiol, 2017; 83: 02508-02516.

5. Beasley SS, Saris PEJ. Nisin-producing Lactococcus lactis strains isolated from human milk. Journal of Applied and Environmental Microbiology, 2004; 70: 5051-5053.

6. Rodriguez E, Martinez MI, Horn N, Dodd HM. Heterologous production of bacteriocins by Lactic Acid Bacteria. International Journal of Food Microbiology, 2003; 80: 101116.

7. Rodriguez EGB, Gaya P, Nanez M, Medina M. Diversity of bacteriocins produced by Lactic Acid Bacteria isolated from raw milk. International Dairy Journal, 2000; 10: 7-15.

8. Reyes-Escogido L, Balam-Chi M, Rodríguez-Buenfil I, Valdés J, Kameyama L, Martínez-Pérez F. Purification of bacterial genomic DNA in less than 20 min using chelex-100 microwave: examples from strains of lactic acid bacteria isolated from soil samples. Antonie Van Leeuwenhoek, 2010; 98(4): 465-74.

9. Patel RV, Kumari P, Chikhalia KH. Fluorinated s-triazinyl piperazines as antimicrobial agents. Z Naturforsch C, 2011. 66(7-8): 345-52.

10. Michel-Briand Y, Baysse C. The pyocins of Pseudomonas aeruginosa. Biochimie, 2002.

11. Scholl D. Phage Tail-Like Bacteriocins. Annual Review of Virology, 2017; 4: 453- 467.

12. Harris ELV. Concentration of the extract: Protein Purification Methods. In: E.L.V. Harris and S. Angal (eds.), a Practical Approach. IRL Press Oxford New York, 1989; 125-172.

13. Jabeen N, Gul H, Subhan SA, Hussain M, Ajaz M, and Rasool SA. Biophysicochemical characterization of bacteriocin(s) from indigenously isolated Agrobacterium radiobacterNA 6. Pak J Bot, 2009; 41: 3227- 3237.

14. DeCourcy K. Column chromatography information manual. Fralin Biotechnology Center. Virginia Technology, 2004; 5-17.

15. Lowry $\mathrm{OH}, \mathrm{NJ}$ Rosebrough, AL Farr and RJ Randall. Protein measurement with the Folin phenol reagent. J Biol Chem, 1951; 193: 265-275.

16. Cafiso V, Bertuccio T, Santagati M, Demelio V, Spina D, Nicoletti G, Stefani S. agr Genotyping and transcriptional analysis of biofilm-producing Staphylococcus aureus. FEMS Immunol Med Microbiol, 2007; 51: 220-227.

17. Shanks RMQ, Dashiff A, Alster JS, Kadouri DE. Isolation and identification of a bacteriocin with antibacterial and antibiofilm activity from Citrobacter freundii. Arch Microbiol, 2012; 194: 575-587.

18. Hancock V, Dahl M, Klemm P. Probiotic Escherichia coli strain Nissle 1917 outcompetes intestinal pathogens during biofilm formation. J Med Microbiol, 2010; 59: 392-399.

19. Lowy FD, Staphylococcus aureus infections. The New England Journal of Medicine, 1998; 339(8): 520-32.

20. Mainous A, Pomeroy C. Management of Antimicrobials in Infectious Diseases. Humana Press, 2001; 349.

21. Cladera-Olivera F, Caron GR, Brandelli A. Bacteriocin-like substance production by Bacillus licheniformis strain P40. Lett Appl Microbiol, 2004; 38(4): 251-6.

22. Waite RD, Curtis MA. Pseudomonas aeruginosa PA01 pyocin production affects population dynamics within mixed-culture biofilms. J Bacteriol, 2009; 191(4): 1349-54.

23. Ling H, N Saeidi, BH Rasouliha, MW Chang. A predicted S-type pyocin shows a bactericidal activity against clinical Pseudomonas aeruginosa isolates through membrane damage. FEBS Lett, 2010; 584: 3354-3358.

24. Arumugam T, Dhanam S, Rameshkumar N, Krishnan M, Kayalvizhi N. Inhibition of Methicillin-Resistant Staphylococcus aureus by Bacteriocin Producing Pseudomonas aeruginosa. International Journal of Peptide Research and Therapeutics, 2018; 25.

25. Yeaman MR, Yount NY. Mechanisms of antimicrobial peptide action and resistance. Pharmacol Rev, 2003; 55: 27-55. 